\title{
Babil Kuneiform Tabletleri ile Antik Kaynaklar Ișı̆̆ında Media, Lydia ve Küçük Asya Fatihi Büyük Kyros
}

\author{
Cyrus the Great - Conqueror of Media, Lydia and Asia Minor in the Light of \\ the Babylonian Cuneiform Tablets and the Ancient Sources
}

\section{Sevgi SARIKAYA*}

Özet: Bu makalede, Büyük Kyros'un İ.Ö. ca. 559 y1lında tahta geçişiyle İ.Ö. 553-İ.Ö. ca. 547/546 y1llarına kadar giriştiği seferler ışığında Pers/Akhaimenid imparatorluğunun kuruluş süreci; siyasi-idari yapılanmasıyla Kyros'un kişiliği ve politikası ele alınmaktadır. Çalışma esas itibariyle döneme ilişkin temel ve başlıca bilgiler veren Babil küneiform tabletleri ve antik kaynaklar çerçevesinde incelenmiştir. Birinci elden dokümanlar, resmi ve güvenilir belgeler olan çivi yazılı tabletlerin azlığı ve özet halinde kaleme alınmasından ötürü, Kyros hakkında en ayrıntılı veriler antik kaynaklardır. Bu nedenle şu ana kadar modern yazarlarca ihmal edilmiş, dağınık halde bulunan antik kaynaklar ve çivi yazılı tabletler derlenerek analiz edilmiş; metinin ilgili kısımlarında detaylıca tartışılmıştır. Bununla birlikte Pers yerel kaynaklarınca adeta efsaneleştirilen krala ait anekdotların yer yer Hellen yazarları tarafindan da kabul görülüp, takip edilmesi Kyros'a ilişkin bir dizi spekülasyona yol açmaktadır. Bu bağlamda küneiform tabletleriyle antik kaynakların kendi içlerinde uzlaştıkları ve ayrıştıkları yanlar belirlenerek efsane ile tarihsel gerçekler ayrıştırılmaya; bununla birlikte Pers kralının bir portresi çizilmeye çalışılmıştır. Ardından tarihsel bilgiler ve modern araştırmalar ışı̆̆ında antik yazarların anlatılarının analizi, tarih yazımlarının irdelenmesi gerekçeleriyle metne eklenmiştir. Çalışma, genel bir değerlendirmeyle sonlandırılmıştır.

Anahtar sözcükler: Kyros, Astyages, Kroisos, Harpagos, Med, Sardeis

Abstract: In this study the establishment of the Persian/Achaemenid Empire, Cyrus' personal qualities, a series of battles and legal regulations put forward by him are discussed with a focus on the time between his enthronement in 559 B.C. and 553 B.C. This study makes use of primary sources such as Babylonian cuneiform tablets and other ancient sources that give us important information concerning the era. Because cuneiform tablets are rather low in number while being written mainly as records, ancient sources are the most detailed resources, which should be taken seriously. Hence, all relevant cuneiform tablets and dispersed knowledge obtained from ancient sources are here analyzed to assemble pieces concerning Cyrus' life. The study concludes by considering the many studies in modern literature on Cyrus' life, since many differences can be seen, a result of how different ancient writers commented on his personality and reign.

Keywords: Cyrus, Astyages, Croesus, Harpagus, Medes, Sardeis

Babil kaynaklarında Anša'nın kralı Kuraš; Ku-ra-aš (Kyros Silindiri: Spek, 1982, 278-283; Kuhrt, 1983, 83-97; Hallo, \& Younger, 2003, 314-317 str. 20-22a; Nabonidos Kroniği: Smith, 1924, 111; 115, II str. 1-4; Grayson, 1975, 104-106, II str. 1-4); Perslerin Küraš ve Kürauš (Kent, 1953, 116-120 col. I. 28; 39; 53; col. III. 25; ayrica bk. 180; Waters, 2004, 93 vdd.) şeklinde adlandırdıkları Büyük Kyros'un (İ.Ö. ca. 559-İ.Ö. ca. 530) soyu, Kyros Silindiri’nden

\footnotetext{
* Arş. Gör., Akdeniz Üniversitesi, Edebiyat Fakültesi, Eskiçağ Dilleri ve Kültürleri Bölümü, Kampüs, Antalya, sevgisarikaya@akdeniz.edu.tr
} 
(str. 20-22) öğrenildiği kadarıyla Teispes’ten (İ.Ö. ca. 650-İ.Ö. 620) başlayarak üç kuşak boyunca Pers hanedanlığına egemen olmuş otokton krallara dayanmaktaydı. Anša (Tall-i Malyan) güney İran'ın dağlık bölgesindeki Elam krallığının doğu kısmının eski şark adıdır. Perslerin Parsa, Hellenlerin de Persis (Fars) şeklinde adlandırdıkları yöreye lokalize edilir. Bölge Assurlular tarafından yıkılıncaya kadar Elam egemenliği altında Susa ve Anša adlı merkezlerden yönetilmiştir. Bazı görüş ayrılıkları olmakla birlikte, genel kabul gören kanıya göre: İ.Ö. 646 yılında Assur kralı Assurbanipal Elamları yenip, Susa'yı yıkınca Persis'te bir otorite boşluğu doğmuştur. $\mathrm{Bu}$ esnada Elam hakimiyetinde uzun süre barış içinde yaşayan Persler, Teispes önderliğinde soylu bir sınıf oluşturmuşlardır. Teispes ve kendisinden sonraki haleflerinin de taşıdıkları unvanlara bakılırsa ("Susa ve Anša kralı", "Anša kralı”) Elam krallığının bir ardılı olarak Pers krallığının temelleri bu sırada atılmış ve giderek güçlenmeye başlamıştır (Balcer, 1995, 43-47; Briant, 2002, 16-23; Brosius, 2006, 6-9; Cook, 1983, 1-10; Curtis, \& Stewart, 2005, 8-28; Dandamaev, 1989, 1-10; Hansman, 1985, 25-34; Stronach, 1997, 35-53; Potts, 2004, 309-314; Wiesehöfer, 2003, 19 vd.).

"Dünyanın krall, büyük kral, güçlü kral, Babil'in kral, Sümer ve Akkad krall, dünyanın dört bir yanının krall, ben Kyros, büyük kral, Anša'nın kralı Kambyses'in oğlu, büyük kral, Anša' nın kralı Kyros'un torunu, büyük kral, Anša'nın kralı Teispes'in soyundan, hüküm sürmesini Bel [Marduk] ve Nebo'nun istediği kral hanedanlı̆̆ının ölümsüz tohuти ...”

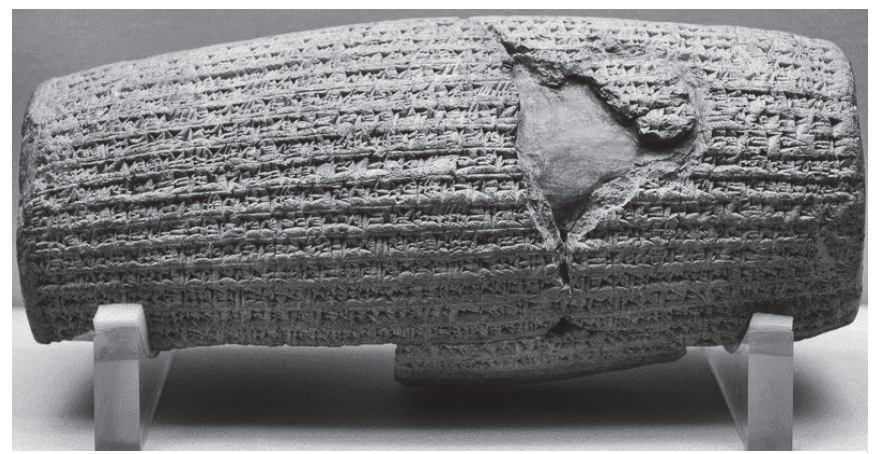

Fig. 1. Kyros silindiri.

(Kyros Silindiri str. 20-22: Spek, 1982, 278-283; Kuhrt, 1983, 83-97; Hallo, \& Younger, 2003, 314-317 str. 20-22a; ayrıca bk. Wiesehöfer, 2003, 78 vd.; Kuhrt, 2007c, 120).

Antik kaynaklarda Kyros'un Teispes-I. Kambyses'e kadarki seleflerine ve Anša'nın kralı olduğuna dair hiçbir veriye rastlanmaz. Kyros başlangıçtan itibaren Persis üzerinde bir hükümdarlık hakkına sahiptir. Plutarkhos (Artaks. I. 2) ve Hesykhios'a (lex. к $4700<$ Kũ oo $>$ ) göre, ismi Eski Persçe'de "güneş" anlamına gelen Kyros, genolojisi Perseus'a dayanan Pers kralı Kambyses'in oğluydu. Herodotos (I. 107-108; ayrica bk. Iust. I. 4. 4) Kambyses'i Persli bir soylu; Ksenophon (Kyr. I. 2. 1; VII. 2. 24) ise, Pers kralı olarak zikreder. Şamlı Nikolaos'un (FGrHist II A F 66) anlatısında, Kyros'un babası Atradates Persli bir haydut; annesi Argoste ise, sığırtmaçtır. Herodotos (I. 74), Ksenophon (Kyr. I. 2. 1) ve Scholia Platon'a (Rep. 566c) göre, annesi İ.Ö. 28 Mayıs 585 yılında Lydia'lılar ve Medler arasında yapılan evlilik antlaşması uyarınca Lydia kralı Alyattes'in kızı Aryenis ile Med kralı Kyaksares'in oğlu Astyages'ten olma Mandane'dir. Knidos'lu Ktesias (FGrHist III C 1 F 9 (1)=Phot. Bib. 72. 36a); Babilli Berossos (FGrHist III C 1680 F 7 d) ve Şamlı Nikolaos (FGrHist II A F 66 (8)=Const. Porph de Insid. p. 23. 23) ise, Kyros ile Astyages arasındaki akrabalık bağını kabul etmezler. Onlara göre, Med kralının kızının adı Amytis'tir. Knidos'lu Ktesias ve Şamlı Nikolaos, Astyages'ın kızı Amytis'i Spitamas adında bir Medliyle; Babilli Berossos ise, Babil kralı Nabopolassar'ın oğlu Nebukhadnezzar'la evlendirdiğini belirtir.

Kyros İ.Ö. ca. 559 yılında Pers tahtına çıktığında, Asya'da Lydia, Med ve Babil krallıkları; Afrika'da ise, Mısır hanedanları hüküm sürüyordu. Kyros'un hükümdarlık süresi konusundaki kaynaklar geneli itibariyle birbiriyle uyumludur (Ktesias (FGrHist III C 1688 F 9 (8)=Phot. Bib. 72. 37a) ve Deinon'a (FGrHist III C 1690 F 10=Cic. div. I. 46) göre, yetmiş yaşında ölen 
Kyros otuz y1l hükümdarlık yapmıştır). Herodotos'a (I. 214) göre, kral yaklaşık yirmi dokuz y1llık hanedanlığı boyunca seleflerinden aldığı küçük Anša krallığını Med, Lydia-Küçük Asya ve Babil fetihleriyle oldukça genişletti. Ardından krallık merkezini Anša'dan, kabilesinin adına izafeten kurduğu Pasargadai'a taşıyarak, 200 y1l boyunca Asya'da hüküm sürecek Pers/Akhaimenid krallığının temellerini attı (Strab. XV. 8. c. 169; ayrıca bk. Kuhrt, 2007d, 372).

Pers krallığının iktisadi ve askeri açıdan giderek güçlenip hakimiyet alanının genişletmesi kısa süre içinde Persleri Medlerle karşı karşıya getirir. Savaşın nedenleri ve gelişim sürecine ilişkin bilgilerimiz görelidir. Antik kaynaklar vasıtasıyla günümüze aktarılan veriler söylenceden öteye gitmezken, Babil çivi yazılı tabletlerinden savaşın gidişatı ve sonuçları hakkında sınırlı da olsa bilgi edinmek mümkündür. Antik yazarlar Persis’te, Pasargadai civarlarında cereyan eden son çarpışmanın Kyros'un Med kralı Astyages'in boyunduruğundan kurtulma, yani Perslerin bağımsızlık savaşımı olduğu hususunda hemfikirdirler (Hdt. I. 125-127; FGrHist II A $90 \mathrm{~F}$ 66=Const. Porph. de Insid. p. 23. 23; Polyain. strat. VII. 6. 1 'Kyros'; Iust. I. 6. 1-7; Dio Khrys. Orat. XXV. 5). Ancak Babil metinleri özgürlük mücadelesinden ziyade, bu durumun iki krallik arasında iktidar ve güç kavgasından kaynaklandığı izlenimini vermektedir (Dandamaev, 1989, 6; Brosius, 2006, 8 vd.). Babil küneiform tabletleri ve antik kaynaklardan edinilen bilgiler doğrultusunda taraflar arasında İ.Ö. 553-İ.Ö. 550 yılları arasında birden fazla muhabere gerçekleşir (antik kaynaklarda bu savaşların art arda mı yoksa üç yıl gibi bir süreye mi yayıldığ tam olarak anlaşılmamaktadır). İ.Ö. ca. 550/549 yıllında Pasargadai civarındaki son savaşta Med kralı Astyages yenilir (FGrHist II A 90 F 66 (39-43)=Const. Porph. de Insid. p. 23. 23; Polyain. strat. VII. 6. 1 'Kyros'; Plut. mor. III. $246 a$-b: Mulier. 5; Alex. LXIX. 1) ve başkent Ekbatana'ya sığınır. Ne var ki, kısa süreli bir ablukanın ardından esir edilir, hazineleri Kyros tarafindan Anša' ya taşınır (Sippar Silindiri I. str. 28-33; Nabonidos Kroniği II. str. 1-4; ayrıca bk. FGrHist III C 1688 F 9 (1) 'Ktesias'=Phot. Bib. 72. 36a).

Babil kralı Nabonidos'un (İ.Ö.ca. 556/5-İ.Ö. 539) hükümdarlığı sırasında kayda geçirilen Sippar Silindiri'nden (I. str. 28-33: Lagdon, 1912, 219-230; Tadmor, 1965, 351-354; Smith, 1924, 44) öğrenildiği kadarıyla Kyros ile Astyages arasındaki savaş görece kronoloji 1şı̆̆ında İ.Ö. 553 yılına tarihlenir. Üç yıl boyunca devam eder. Herodotos (I. 127), Şamlı Nikolaos (FGrHist II A 90 F 66=Const. Porph. de Insid. p. 23. 23) ve Polyainos (strat. VII. 6. 1 'Kyros')' da taraflar arasında birden fazla çarpışmanın gerçekleştiğini aktarırlar. Sippar Silindiri'ne göre, Nabonidos krallığının ilk yıllında (İ.Ö. 555) Marduk'u rüyasında görür. Marduk ona, İ.Ö. 609 y1lında Assur egemenliğindeki Harran'da (Sultantepe) vuku bulan Med-Assur savaşı esnasında Medler tarafından yıkılan Sin'e adanmış Ehulhul Tapınă̆ı'’nı restore etmesini buyurur (Dandamaev, 1989, 18). Nabonidos rüyasında tanrıya bu bölgenin karşı konulamaz güçte olan Med krallı̆̆ının hakimiyetinde olduğu yanıtını verir. Tanrı da ona, Med kralı Astyages'ten artık korkmamasını telkin eder. Zira, Harran Bölgesi’nin Medlerin elinden kurtulacağını kendisine vahyeder (I. str. 28-33):
"Ne senin bahsettiğin Umman-Manda [Medler] ne ülkeleri ne de onları destekleyen krallar var olacaklar. [Gerçekti], üçüncü yılına [İ.Ö. 553] geldiği zaman, Marduk, Anša kralı Kyros'u ona karşı sürdü, kendi genç hizmetçisini (ardu); Kyros, küçük ordusuyla Umman-Manda'nın (Med kralının) büyük ordusunu dağıttı ve Med kralı, Astyages'i ele geçirdi ve kendi ülkesinde onu esir etti”".

Synkronolojik/eş zamanlı olarak Nabonidos'un yedinci yılına, İ.Ö. ca. 549'a tarihlenen Nabonidos Kroniği'nde (II. str. 1-4: Smith, 1924, 111; 115; Pritchard, 1969², 305; Grayson, 1975, 104106; Glassner, 2004, 235 n 26; Kuhrt, 2007c, 122) ise, açıkça Kyros'un zaferinden söz edilir. Tablete göre, Astyages büyük bir orduyla Kyros'la savaşmak için ilerler. Herodotos'un (I. 123; 127) anlatımıyla da uyuşan metne istinaden son muharebe Ekbatana (Hamadan) civarında yap11ır. Savaş Med kralının komutanlarının/askerlerinin ihaneti nedeniyle yenilip Kyros'a esir düş- 
mesiyle sonuçlanır (II. str. 1-4):

\author{
“[Astyages] [ordusunu] silahlandırdı ve Anša krall Kyros'u ele \\ geçirmek için ilerledi [...] | ordu Astyages'e (Ishtumegu) karşı isyan etti \\ ve esir alınd. [Onlar onu] Kyros'a [teslim ettiler] [. . .]. | Kyros kral \\ kenti Ekbatana'ya (Agamtanu) doğru ilerledi. Gümüş, altın, mal, servet, \\ [. . .] | Ekbatana'da ele geçirdiği ganimetleri Anša'a taşıdı. Ordunun \\ esya ve servetini [.. .]".
}

Perslere ilişkin anlatısı sınırlı sayıdaki Doğu kökenli belgelerle kısmen desteklenen; bu bağlamda Pers tarihi üzerine başka kaynaklardan edinemeyeceğimiz ender bilgiler veren Herodotos'tan (I. 127; ayrıca bk. Iust. I. 5. 8; I. 6. 1-17) isyancıların elebaşının Med kralının sağ kolu ve akrabası Harpagos olduğu anlaşılmaktadır. Komutanın ihanetinin sebebi Astyages'in acımasızca öldürttügü oğlunun intikamını almaktır. Bu yüzden savaşın kritik bir anında Harpagos ile yandaşları taraf değiştirirler. Savunmasız kalan Astyages ikinci muhaberede komutanlığı bizzat kendi üstlenmek zorunda kalır. Ancak yenilip esir edilir. Böylelikle otuz beş yıl süren hanedanlığ İ.Ö. ca. 550/549 yılında Med krallığıyla birlikte tarih sahnesinden silinir (ayrıca bk. Drews, 1969, 1-11).

Medlerin Pers boyunduruğu altına girmesine ilişkin iki farklı tradisyon daha vardır. Bunlardan ilkinde Ksenophon, Pers kralının biyografisi niteliğindeki Kyros'un Eğitimi adlı eserinde, olayları genel kabul gören literatürün dışında ele alır (VIII. 5. 18-20). Yazara göre, dedesi Astyages'le Kyros arasında herhangi bir anlaşmazlık söz konusu değildir. Hatta Kyros on iki yaşından sonra, Media'da dedesinin denetiminde süvari eğitimi alır. Astyages ölünce Med tahtına halefi Kyaksares geçer. Kyros dayısıyla birlikte Assur, Lydia, Babil krallıklarına karşı savaşarak düşmanlarını birbiri ardına ağır yenilgilere uğratır. Kyaksares, Kyros'u bu başarılarından; ayrıca tahta veliaht atayacağı halefi olmadığından ötürü Babil seferinden sonra kızıyla evlendirir. Tek varisine çeyiz olarak Media'yı vermesiyle de Med krallığı Kyros'un hakimiyeti altına girer.

Konuya ilişkin diğer bir versiyon ise, ana hatlarıyla Şamlı Nikolaos (FGrHist II A 90 F 66) tarafından kaleme alınmıştır. Tarihçiye (FGrHist II A 90 F 66 (11-16)=Const. Porph. de Insid. p. 23. 23) göre, yoksul bir ailenin çocuğu olan Kyros, Med sarayına gelip ilk önce önemsiz görevler -sarayın iç-dış dekorasyonculuğu; 1şık taşıyıcılığını- üstlenir. Zamanla Astyages'in sakiliğine kadar yükselir. Kralın en güvendiği adamlarından biri olmayı başarır. Annesinin kendisine ilişkin rüyasını Babilli bir önbilicinin kral olacağına yorması nedeniyle Astyages'i tahtından devirmeye karar verir. Gerekli hazırlıkları tamamlayıp Persleri silahlandırır. Medlerin ezeli düşmanlarından Kadusia'lılarla müttefiklik arayışı içine girer. Ardından çeşitli bahaneler ileri sürerek Astyages'ten Persis'e gitmek için izin alır. Ancak bölgede konuşlanır konuşlanmaz komplo planları açığa çıkar (FGrHist II A 90 F 66 (24-26)=Const. Porph. de Insid. p. 23. 23). Astyages büyük bir orduyla Kyros'un üzerine yürür. Kyros savaş başlamadan önce Pers kadınlarını ve çocukları güvenlikleri için Pasargadai'ya nakleder. Şamlı Nikolaos'a (FGrHist II A 90 F 66 (39-43)=Const. Porph. de Insid. p. 23. 23) göre, Persler ve Medler arasında birkaç çarpışma vuku bulur. Hyrba civarlarında gerçekleşen (yeri tam olarak lokalize edilememektedir) ikinci muharebede Kyros'un babası Atradates yakalanarak aldığı ağır yaralardan ötürü yaşamını yitirir. Kyros ve adamları Pasargadai'ya çekilmeye mecbur kalırlar. Med askerleri onları yakın takibe alarak ağır kayıplara uğratırlar. Polyainos'a (strat. VII. 6. 1 'Kyros') göre de, Medler üç farklı cephede Persleri yenmiş ve Pasargadai önlerinde gerçekleşen dördüncü çarpışmada da düşmanlarını sıkıştırıp kente kaçmak zorunda bırakmışlardır. Persler kente sığınmak üzereyken, kadınlar onları korkaklıkla itham edip, özgürlükleri uğruna gerekirse ölmeleri hususunda diretince, askerler tekrar düşmanın üzerine atılırlar. Kyros yaptığı ani manevra hareketiyle düşman saflarını yararak Medleri ağır bir bozguna uğratır (ayrıca bk. Polyain. strat. VII. 6. 1 'Kyros'; Plut. mor. III. $246 a$-b: Mulier. 5; Alex. LXIX. 1). Polyainos (strat. VII. 6. 1 'Kyros') Pasarga- 
dai'daki bu son savaşta Perslerin Med krallığını sona erdirecek kesin bir zafere nail olduklarını aktarır. Şamlı Nikolaos (FGrHist II A 90 F 66 (43-45)=Const. Porph. de Insid. p. 23. 23) ise, Astyages'in kısa bir süre daha muhasarayı sürdürdüğünün altını çizer. Sonunda Parthia, Sakia, Baktria' lıların yardımlarıyla Med krallığı çökertilir ve Astyages esir alınır.

Historiograflar (Hdt. I. 130; FGrHist III C 1688 F 9 (1-6) 'Ktesias'=Phot. Bib. 72. 36a; Iust. I. 6. 8-17; Tzetz. chil. I. 87) Kyros'un Astyages'in hayatını bağışladığı ve himayesi altında tutuğu konusunda hem fikirlerdir. Knidos'lu Ktesias'a (FGrHist III C 1688 F 9 (1-6) 'Ktesias'= Phot. Bib. 72. 36a; ayrıca bk. Tzetz. chil. I. 87-100) göre, Kyros mağlubiyetinin ardından Ekbatana'ya kaçan Astyages'i teslim alır ve zincire vurdurur. Ancak kısa süre sonra Astyages'i serbest bırakır. Ardından Parikanioi'la özdeşleştirilen Barkanioi'ın ülkesine vali atar (Hdt. III. 92). Iustinus'a (I. 6. 16) göre, yenilgisinin ardından Media'ya dönmek istemeyen Astyages'i Hyrkania'lıların ülkesine vali yapar. Ktesias'ın (loc. cit.) anlatısına göre, Astyages Pers kralının hadımları tarafından gizlice öldürülecek kadar Kyros'un üzerinde önemli ölçüde söz sahibi olmuştur.

Bu süreçte, İ.Ö. ca. 550/549 yılından itibaren Kyros, imparatorluğun hakimiyet merkezinin sürekli büyümesini ve genişlemesini sağladı. İ.Ö. 585 yılındaki Medler ve Lydia'lılar arasındaki Halys (Kızıl) Irmağı'nı hudut yapan antlaşmanın iyi yürüdüğü, her iki tarafın da buna sadık kaldığı anlaşılmaktadır (sözleşme akdi için bk. Hdt. I. 74; Cic. div. I. 49. 112; Oxyrh. Pap. 2506 F 98; ayrica bk. Huxley, 1965, 204; How, \& Wells, 1975' , I 93 vd.; Lapini, 1999, 115 vd.; Asher, Lloyd, \& Corcella, 2007, 134 vd.). Ancak Med krallığının yıkılması otorite boşluğunun doğmasına yol açtı. Büyük bir olasılıkla Kroisos, Perslerin kendisine fazla mukavemet gösteremeyeceğini varsaymaktaydı. Bundan hareketle seleflerinin tasarladığı Kappadokia’yı ele geçirip bu bölgenin olanaklarından yararlanmayı; böylelikle Mısır ve Babil'le siyaset ve ticaret ağını genişletip zamanla hakimiyet alanlarını Merkezi Asya'ya kadar yaymayı planlamıș olsa gerekti. Herodotos'un (I. 50-51) belirtiği üzere Kroisos'un bu planlarını harekete geçirebilmesi için Kyros'un eniştesi Astyages'i devirmesini savaşın nedeni sayması gayet yeterli bir sebepti. Dindar Kroisos gerekli hazırlıkları yaparken, bir yandan da çeşitli kehanet ocaklarına elçiler gönderip görkemli sunularla (Diod. IX. 10. 6; XVI. 56. 6; Paus. III. 10. 6; X. 8. 7; Ath. Deip. VI. 20; Plut. mor. VII. $556 f$ : De sera 12) güvenirliklerini sinamaktan geri kalmiyordu. Bilici merkezlerinin Delphoi'daki Apollon Pythios ve Oropos yakınlarındaki Amphiaraos Tapınăğ'nın (SEG 31. 418; Syll ${ }^{2} \mathrm{n}^{\circ}$ 334=Sherk 1969, no 23 str. 43-49; tapınak için ayrıca bk. Hdt. VIII. 134. 2; Strab. IX. 2.10 c. 404; IX. 2.11 c. 404; Paus. IX. 8. 3; 19. 4; Diog. Laert. II. 142; Cic. de nat. deor. III. 49)- karmaşık ve her anlama çekilebilen kehanetleri kendince yorumladı (Bu tapınaklara "Perslerle savaşsın mi, savaşacaksa dost bir ulustan da birkaç bölük alsın mi?" diye sordurttu. İki orakı1 "Perslerle savaşa girerse, büyük bir imparatorluğu devirecektir" yanıtının yanı sıra, Hellenlerin en güçlüleriyle bağlaşıklık kurmasını salık verdi (Hdt. I. 53). Ayrıca bilici merkezleri Kroisos'a "Halys'ü geçerse büyük bir imparatorluk ylkılacak" kehanetinde bulundular (Aristot. Rhet. III. 1407a 5. 4; Diod. IX. 32; FGrHist II B 250 F 11 'Kastor'=Malal. Chron. VI. 8 c. 156; Cic. div. II. 115; Suda $\kappa 2500$ s.v. $<$ Kooĩ $\sigma o \varsigma=$ Kroisos $>$; Schol. Lucian XXI. 20 272; Const. Porph. de Virt. I. 220. 9). Herodotos'a (I. 55=Schol. Plat. Rep. 566c; Diod. IX. 31. 2) göre, Lydia kralı bu sefer saltanatı uzun olup olmayacağını danışmak için Delphoi’ya üçüncü kez elçiler gönderdi. Pythia ona "günün birinde katır Medlere kral olacak, o zaman ey yumuşak ayaklı Lydia'lı kaç" uyarısında bulundu. Ancak bu kehaneti de keyfine göre yorumlayan -katırın bir ima ve sözü edilen şeyin Kyros olduğunu anlamayan- Kroisos'un Persleri yeneceği hususunda artık hiç şüphesi kalmadı (Hdt. I. 90-91; FGrHist II A 90 F 68 (13) 'Nikolaos'= Const. Porph. de Virt. I. 345. 19; Schol. Plat. Rep. 566c; Diod. IX. 31. 2; Val. Max. I. 7. 5).

İ.Ö. ca. 548/547 yılında yakın ilişkilerinden ötürü Kroisos (Hdt. I. 69; ayrıca bk. Ath. Deip. VI. 20; Paus. III. 10. 6), Lakedaimon'lularla (Hdt. I. 69; Ksen. Kyr. VI. 2. 9-10; Plut. mor. XI. 859 c; De Herod. 21; Ath. Deip. VI. 20; Paus. IV. 5. 3; III. 2. 3); ayrica Misir ve Babil'le (Hdt. 
I. 77; Ksen. Kyr. VI. 2. 10) dost ve müttefiklik antlaşması yaptı. Mısır ile Babil'in Lydia krall1ğıyla ittifak ilişkisine girmesi, Merkezi Asya'da Pers krallığının gücünü ve hissedilmeye başlanan potansiyel tehlikeyi göstermesi bakımından önemlidir.

Hazırlıkları tamamlayan Kroisos sonbaharın sonlarına doğru Kappadokia'ya ilerledi. Ordusuyla Halys Irmağı'nı aşıp, bölgenin en tahkimli yeri olan Pteria'ya (Kerkenes Dağı/Aka-

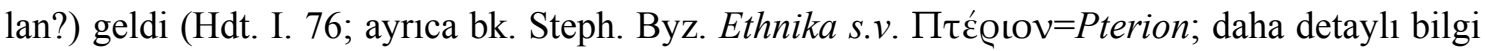
için bk. Summers, Baturayoğlu, Harmansah, \& McIntosh, 1996, 201-234; Müller, 1997, 208-213; Dönmez, 2004, 74 vdd.; Asher, Lloyd, \& Corcella, 2007, 136). Burayı ve civar yerleşkeleri zapt ederek, otokton halklardan Suriyelileri göçe zorladı. Kyros ise, hazırladığı büyük bir orduyla Kroisos'a karşı yürüyüşe geçti. Lydia kralına ayaklanıp, kendi saflarında yer almaları için Ionia'lllara önceden elçiler gönderdi (Hdt. I. 76; Diod. IX. 35). Miletos haricinde, Lydia ordusunun gücüne ve ülkeleri arasındaki mesafenin uzaklığına güvendiklerinden tehlikenin önemsizliğine kanat getiren diğer Ionia kentleri Kroisos'a sadakatlerini sürdürdüler (Harpokration'a (lex.

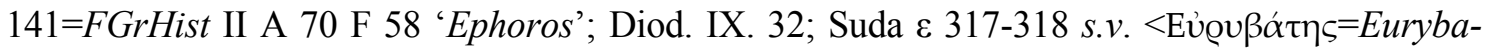
tos $>$ ) göre, Ephoros sekizinci kitabında Ephesos'lu Eurybatos'un Perslerle yapılacak savaş için bir ordu hazırlanmak amacıyla Kroisos'tan para aldığını anlatır. Ancak daha sonra Kroisos'a ihanet eder ve elindeki bütün parayı Kyros'a verir. Bu olaydan dolayı bu tür hilekarlara Eurybatos dolandırıcıları denir). Miletos ise, Sardeis kuşatmasında Kyros'a asker yardımı göndermekle Pers bağlaşıklığını tanıdı (Hdt. I. 75: Diogenes Laertios'a (I. 25) göre, Miletos'lular siyasi konularda Thales'in danışmanlığından yararlanırlardı. Kroisos ittifak ilişkisine girmek için Miletos'a elçiler gönderince, filozofun kararıyla bağdaşıklık reddedildi. Thales'in hükmü Kyros'un zaferiyle kentin kurtuluşunu sağladı (ayrıca bk. Briant, 2002, 36).

Kyros Arbela'nın (Erbil) aşağısındaki Tigris’i aşıp, Kilikia Kapıları'ndan (Gülek Boğazı) Kappadokia'nın içlerine girdi (Nabonidos Kroniği: Smith, 1924, 112; 116, II str. 15-18; Grayson, 1975, 104-107, II str. 15-17; Pedley, 1972, 83; ayrica bk. Young, 2006 6 , 33). Ordusuyla Pteria'ya gelip, Lydia ordugahının karşısına konakladı. Diodoros (IX. 32. 3)'de Kyros Kappadokia'ya geldiğinde, Perslerin bir kölesi olduğunu kabul ederse, önceki suçlarını bağışlayacağını ve Lydia'ya satrap atanacağını bildirmek üzere bir elçi heyeti gönderdi. Lydia kralı, elçilere Kyros ve Persler Kroisos'u köle almayı tasarliyorsa, kendisinin herhangi birinden asla emir almadığını ve bu vakte kadar Perslerin Medlerin bir kölesi olduklarını unutmamaları gerektiği yanıtını verdi (Suda $\kappa 2500$ s.v. $<$ Kooĩ $\sigma o \varsigma=$ Kroisos $>$ )'de iki kral arasında gerçekleşen yazışma/ diyalogda Lydia kralının Kyros'a bir nota verdiğini belirtir. Kroisos, Kyros’a şunu yazdı: "Sana krallı̆̆ını teslim etmeni emrediyoruz. Çünkü o başlangıçtan itibaren bizimdi ve sınırlarımıza dahildi. Üzerine saldırdığımızda bize karşı direnemeyeceksin ne de bizim engin gücümüz karşısinda iyi bir şansa nail olabileceksin". Kyros ise, karşılığında şu yanıtı verdi: "Hayallerinde bütün dünya sana yetmiyorsa, o vakit bize söylediklerin güzel şeylerdir. Ancak bütün bu yerlerin efendisi olarak, bizim yerlerimizi de istiyorsan, bilesin ki bizimle savaşında iyi bir talihin getirdiği bu başarı devam etmeyecek". Ardından Kyros, India territorium'una ilerlemeye ve Kroisos'un acımasızlığından kaçmaya niyetlendi. Karısı Bardane onun bu planlarını fark etti. Kyros'a bir zamanlar kendisi ile Dareios için bilicilik yapan Kudüslü kahin Danieltos'a danışmasını salık verdi. Ondan Kroisos'u yeneceğini ve bunun için ne tür hazırlıklar yapması gerektiğini öğrendi. Malalas (Chron. VI. 7-11 c. 154-158)'de Suda'nın (loc. cit.)'deki pasajından yaptığı alıntıya istinaden, Kroisos ve Kyros arasındaki savaşı Suda gibi gerçeği yansıtmayan ve oldukça farklı bir şeklide kaleme alır. Örneğin Med ve Pers hükümdarlarını birbirleriyle karıştırmış; Medlerin hepsini Pers kralları olarak sunmuştur. Malalas'a (Chron. VI. 7- c. 154155) göre, Kyros Pers kralı Astyages'in oğluydu. Astyages'in selefi ise, Dareios'tu [Med kralı Deiokes]. Kyros'un evlendiği Barene, bu Dareios'un karısıydı).

Pteria'da sonucu belirsiz bir savaş oldu (Hdt. I. 76: Kastor'a (FGrHist II B 250 F 11=Malal. 
Chron. VI. 8 c. 157) göre ise, çetin bir kış mevsiminde vuku bulan bu savaşta Kroisos yenildi ve esir alınd1). Ertesi gün taraflar arasında mücadele devam etmeyince Kroisos derhal Lydia'ya çekildi (Hdt. I. 77). Polyainos'a (strat. VII. 8. 2 'Kroisos') göre, Kappadokia'daki hezimetin ardında Kroisos, ordusunu düzenli bir şekilde ve olabildiğince az kayıpla geri çekebildi. Bunu şu stratejisi sayesinde gerçekleştirdi: Askerlerin her birine taşıyabilecekleri kadar odunu kendileriyle birlikte getirmelerini emretti. Dar bir geçide odunları yığdırdı. Kyros'un takibinden ötürü bütün hızıyla gece boyunca yürüyüşüne devam etti. Süvarilerden bir kısmını geride bırakarak günün ilk ışığıyla onları yakmalarını emretti. Bu sayede Kyros'un takibi engellendi.

Kroisos Lydia'ya geldiğinde ordusundaki paralı askerleri terhis etti. Başarısızlığını asker sayısının azlığına bağladığından, müttefiklerinden oluşan büyük bir orduyla ilkbaharda Kyros'la ikinci muhabereye girişmeye karar verdi. Mısır kralı Amasis, Babil kralı Nabonidos'a ve Lakedaimonia'ya elçiler gönderdi (Hdt. I. 77; ayrıca bk. Ksen. Kyr. VI. 2. 10). Büyük olasılıkla Miletos'tan da müttefiklik ve yardım talebinde bulundu (Diog. Laert. I. 25). Dört ay sonra Sardeis'te kendisiyle buluşmalarını rica etti (Hdt. I. 78). Pers kralı ise, bağlaşıkların yardımıyla düşman birliklerinin toparlanıp daha da güçlenmesi engellemek için Hermos (Gediz) Ovası'na gelip mevzilendi. Hazırlıksız yakalanan Kroisos askerlerini derhal savaş düzenine soktu. İki ordu kentin önündeki uçsuz bucaksız ovada yeniden karşılaştı. Kroisos ön saflara oldukça güvendiği Lydia süvarilerini dizdi. Kyros hileyle bu taburu etkisiz hale getirmeyi başardi. Herodotos (I. 79-80) ve Polyainos'a (strat. VII. 6. 6 'Kyros') göre, Lydia süvarileri Pers askerlerinin üzerine bindiği develer sayesinde saf dışı bırakıldı. Zira, atlar yapıları gereği develerin kokusuna ve görüntüsüne tahammül edemezlerdi. Ksenophon (Kyr. VII. 1. 47-49) bu savaş hilesini kesinlikle reddeder. Kyros'un zaferi müttefiklerinin gösterdiği büyük gayretlere ve Pers süvarileriyle oraklı savaş arabalarına borçlu olduğunu belirtir. Sonuç olarak, Kyros Lydia'lıları surların arkasına akropolis'e çekilmeye zorlayarak kenti ablukaya aldi.

Ksenophon ve ondan alıntılayan Zonaras, Tzetzes gibi yazarlardan Lydia'nın fethine ilişkin farklı bir anlatı daha bilinmektedir. Ne var ki, aktarımların tarihsel gerçeklik değeri yoktur. Zira, İ.Ö. 612 y1lında Med ve Babil koalisyonu sonucunda ağır bir darbe alan Assur imparatorluğunun İ.Ö. 608 yılında tarih sahnesinden tamamen silindiği bilinmektedir (Babil Kroniğ $i$ str. 1-49: Grayson, 1975, 90-94; Glassner, 2004, 218-224; ayrıca bk. Oates, $2006^{6}, 178$ vdd.). Üstelik Babil çivi yazılı tabletleriyle antik kaynaklar Med ve Pers düşmanlığını gözler önüne sermektedir. Ksenophon'un (Kyr. I. 5. 2-3; ayrica bk. Tzet. chil. I. 1 str. 63-87) anlatısına istinaden, Asya kentleri için asıl tehlikeyi Med krallığının Perslerle yapılan evlilik antlaşmasıyla engellenemez yükselişi ve emperyalist politikası oluşturmaktaydı. Bu durumdan endişe duyan Assur kralı Medlerle yapacağı savaşta bütün müttefiklerine: Lydia; Kappadokia; Büyük Phrygia ile Hellespontos Phrygia'sına; Paphlagonia; India; Karia ve Kilikia'ya elçiler gönderir. Ordularıyla hazır bulunup kendisine asker ve silah yardımın da bulunmalarını rica eder. Karia, Kilikia ve Paphlagonia'lılar kralının bu çağrısını yanıtsız bırakırken, Lydia kralı Kroisos; Büyük Phrygia kralı Artakamas; Kappadokia kralı Aribaios; Arabia kralı Aragdos büyük bir orduyla; Hellespontos Phrygia'sından ise, Gabaidos önderliğinde bir birlik Kaystros (Küçük Menderes) Ovası'na doğru yola çıkar. Ksenophon (Kyr. III. 3. 43-66)'de Assyria territorium'unda gerçekleşen ilk çarpışmada Assur kralı büyük bir direniş sergileyemeden, bozguna uğrar ve ölür. Ordunun geri kalan kısmı Pers-Med askerlerince sıkıştırılıp kılıçtan geçirilirken, sayıca üstün olan Assur müttefiklerinin saldırılarıyla düşman birlikleri geri çekilir. Ertesi gün Assur ve bağlaşıkları düzensiz bir sıra halinde ilerlerler. Kyros takiple düşmanın üzerine aniden atılır. Bu saldırıda Kappadokia'lılar ve Arap'lar büyük kayıplar verirken, Lydia kralı Kroisos, Hellespontos Phrygia'sının komutanı Gabaidos ve Phrygia kralı herhangi bir zayiat vermeden kurtulurlar (Kyr. IV. 1. 8; 2. 29-31). İlk muharebenin ardından Assur müttefikleri Kroisos'u bileșik orduların başkomutanı seçtiler ve asker toplamaya başladılar (Kyr. VI. 2. 9-10). Sardeis önlerinde yapılan ikinci 
savaşta Kroisos ile bağlaşıkları tekrar bozguna uğradılar (Kyr. VII. 1. 44-46; Iust. I. 7. 1-10). İttifak kentler ülkelerine kaçarken, Kroisos Lydia'ya çekildi. Surlara savaş makineleri ve kuleler yerleştirilmek suretiyle Sardeis akropolis'i kuşatıldı.

Mermnades sülalesi zamanında inşa edilen anıtsal savunma duvarları ve akropolis' in coğrafik konumundan antik yazarlarca işgal edilmesi imkansız olarak düşünülen Sardeis'in İ.Ö. ca. 547/546 yılında düşüşüne ilişkin birbirinden değişik tradisyonlar söz konusudur. Antik yazarların genelinin anlatımında kentin zapt edilmesinin bir hile ya da ihanet sonucunda gerçekleştirildiği hikaye edilmesi bu yaklaşımın birer yansıması olsa gerektir. Herodotos (I. 80-84)'de muhasaranın on dördüncü gününde, akropolis'in dik bir köşesinden düşürdüğü miğferini almaya inen Lydia'lı bir askeri Perslerin görüp savunmasız bırakılmış bu yerden iç kaleye tırmanmalarıyla kent zapt edildi. Ksenophon'a (Kyr. VII. 2. 1-4; ayrıca bk. Zon. epit. hist. III. 23b) göre, Lydia'da ikamet eden bir Perslinin iç kaleye giden gizli yolu Kyros'a göstermesiyle Sardeis düştü. Knidos'lu Ktesias (FGrHist III C 1688 F 9 (4-5)=Phot. Bib. 72.36 b); Polyainos (strat. VII. 6. 10 'Kyros') ve Frontinus'un (strat. III. 8. 3) anlatısında ise, kuşatma esnasında Kyros surlara eş yükseklikte tahta makineler yaptırtır. Üzerlerine Pers savaşçı askerlerinin kuşandıkları gibi kıyafetlerle, sakallarla ve omuzları ok kılıflarıyla donatılan heykeller yerleştirir. Geceleyin bu makineler kaleye bakan surların dibine kadar götürülür. Şafak söktüğünde Kyros düşmanın dikkatini farklı yöne çekmek için saldırılarına hız verir. Lydia'lılar büyük bir direniș sergilerler. Bu sirada makinelerin üzerinde yatay duran cansız mankenler havaya kaldırılır. Lydia'lılar bir an etrafa bakıp karşı surlardaki heykelleri görünce, düşmanın kaleyi ele geçirdiğini zannederler. Her taraftan kuşatıldıkları korkusuyla endişelenip kentin kapılarını açarlar. Sardeis bu sayede Perslerin eline geçer. Polyainos (strat. VII) bir diğer versiyonunda bu olayı farklı şekilde hikaye eder. Sardeis önlerinde cereyan eden savaşın ardından Kyros ile Kroisos aralarında ateşkes ilan ederler. Kyros kenti terk ediyormuş gibi yapar; ancak geceleyin ani bir saldırıyla Sardeis'i alır. Ancak Kroisos akropolis'i elinde tutarak Hellenlerin kendisine yardıma gelmesini beklemeye koyulur. Kyros esir edilen Lydia'lıları sergileyerek akropolis'tekilere teslim olurlarsa, akrabalarını serbest bırakacağını; aksi halde herkesi kent meydanında asacağını bildirir. Lydia'lılar, Kroisos'un yardım geleceğine dair boş ümitlerini beklemeden sevdiklerinin güvenliği için akropolis'i Pers kralına teslim ederler. Parthenios (amat. 22) ise, Kroisos'un kızı Nanis'in Pers kralına aşkından ötürü babasına ihanet ettiğini ve bu şekilde Sardeis'in ele geçirildiğini aktarır. Nanis evlenme koşuluyla Kyros'la gizlice anlaşır. Suç ortaklarıyla birlikte, kalenin tahkimli bir yerinden düşmanın içeri girmesini sağlar. Sardeis düşer; ancak Kyros, Nanis'e verdiği sözü tutmaz (Sardeis'in düşüşüne ilişkin olarak ayrıca bk. Favorin. fort. 22; Iust. I. 7. 3-10; Theon, progym. 7; Diog. Laert. II. 3; Tzet. chil. I. str. 90-103).

Sardeis fethinde Kroisos da sağ ele geçirilmiştir. Akabinde Kroisos ve on dört Lydia gencinin yakılmasına; Kyros'un merhamete gelip, Apollon vasıtasıyla ateşi söndürmesine ilişkin olay anlat1lur (Hdt. I. 86-87; Bacchyl. III. 23-62; FGrHist II A 90 F 68 (1-13) 'Nikolaos'=Const. Porph. de Virt. I. 345. 19; Plut. Sol. XXVIII. 1-6). Antik ve modern yazarlarca bu hadisenin gerçekliğine hep kuşkuyla yaklaşılmıştır (Plut. Sol. XXVII. 1-2). Zira, Pers dininde ateş kutsaldır. Herodotos (III. 16) ve Şamlı Nikolaos'un (FGrHist II A 90 F 68 (11-12)=Const. Porph. de Virt. I. 345. 19) da belirttiği üzere Persler ateşi tanrısal cevherden saydıklarından, Zoroastres (Zerdüşt) yasaları uyarınca ateşin ne ceset yakılarak ne de buna benzer faaliyetlerde bulunarak kirletilmesi yasaktır. Bu gibi nedenlerle bazı antik yazarlar eserlerinde bu hikayeye yer vermezler (Ksen. Kyr. VII. 2. 9-29; FGrHist III C 1688 F 9 (4-5) 'Ktesias'=Phot. Bib. 72. 36b; Philostr. de Imag. II. 9. 2-5; FGrHist II B 250 F 11 'Kastor'=Malal. Chron. VI. 8 c. 157). Ancak şurası bir gerçektir ki, Kyros Astyages'e sağladığı itibarın aynısını Lydia kralına da göstermiştir. Kroisos'u Persis'e götürmüş ve baş danışmanlarından biri yapmıştır. Ekbatana civarlarındaki Barene kentini ona tahsis etmiştir (FGrHist III C 1688 F 9 (5) 'Ktesias'=Phot. 
Bib. 72. 36b; Iust. I. 7. 3-10). Nikolaos (FGrHist II A 90 F 68 (14)=Const. Porph. de Virt. I. 345. 19)'de bazılarının ise, Kyros'un Lydia yönetiminde yasal bir değişiklik yapmadıysa, kenti Kroisos'a bırakmış olabileceğini aktardıklarına değinir. Hatta Kyros, Massagetlere karşı düzenlediği son seferi sırasında Kroisos'u veliahttı Kambyses'e danışman olarak bırakmıştır (Hdt. I. 208; ayrica bk. West 2003, 416-437).

Sardeis'in düşüşü antik kaynakların yanı sıra epigrafik belgeler ve arkeolojik verilerle de kanıtlanmaktadır. Sardeis kazılarında ortaya çıkan sur dibindeki ve diğer kısımlardaki evlerde savaşın yaratığı tahribatın göreceli olarak bu döneme tarihlenebileceği iddia edilmektedir. Bu yapı evresi sırasında ele geçen ağır darbeler sonucunda hayatını yitiren iki asker iskeletinin Kroisos ile Kyros harbinden kaldığı düşünülmektedir (Cahill, 2010, 339-361). Nabonidos Kroniği'nden (Smith, 1924, 112; 116, II str. 15-18; Grayson, 1975, 104-107, II str. 15-17; Pedley, 1972, 83; Kuhrt, 2007c, 123) ise, İ.Ö. 547 yılında Pers kralı Kyros'un Tigris'i aşıp Küçük Asya'ya girdiği ve Kroisos'u yenip Sardeis'i ele geçirdiği belgelenmektedir (17. satır: S. Smith (1924, 116 II)'de i-bir-ma yerine i-rab(!)-ma okumasından kaynaklanan hatadan ötürü "kralı öldürdü" şeklinde çevirmiştir (Grayson, 1975, 106). Yanlış tercüme nedeniyle 16. satırdaki fragman halindeki $L u$ (dia) tamamlaması modern yazarlarca muallak kalmıştır (Frye, 1983, 92). A. K. Grayson'un (loc. cit.)'de 17. satırdaki düzeltmesiyle ve şu ana kadarki alternatif önerilerin desteksizliği nedeniyle metindeki söz konusu kentin Lydia olma olasıllğı güçlenmektedir).

\section{Nisanu (Nisan) ayında Parsu krall Kyros ordusunu topladı ve 16 Arbela'nın (Erbil) aşağısından Tigris'i geçti (?). Iyyar ayında (Mayıs) Lu(dia?) 'ya [ilerledi]. \\ 17 Krall yendi, ganimet ald, orda bir garnizonunu kurdu. 18 Daha sonra kral ve garnizon orada kaldl.}

Lydia'nın düşüşüyle birlikte Batı Anadolu kentleri birer birer Pers boyunduruğunu tanımak zorunda kaldı. Lydia egemenliği altındayken bağımsızlıklarını sürdüren; olasılıkla sadece Kroisos'a vergi/haraç vermekle mükellef tutulan Ionia ve Aiolia'lllar, Kyros'a daha Sardeis'teyken elçiler gönderip, Kroisos'a bağlı oldukları koşular altında Pers egemenliğini tanımaya hazır olduklarını bildirdiler. Sardeis fethiyle Kyros Lydia krallığının bir ardılı olarak, Batı Anadolu kentlerinin de artık hakimiydi. Egemenliğinin kayıtsız şartız kabullenmesini istediğinden, Perslerin dost-ittifak teklifini reddetmelerini öne sürerek onları geri çevirdi (Hdt. I. 76; Diod. IX. 35). Miletos haricindeki bütün Ionia'lılar Panionion'da Perslerle mücadele için bir araya gelip, direniş hazırlıklarına başladılar (Hdt. I. 147). Sparta'lılardan yardım talep ettiler; ancak bu çağrıları yanıtsız kaldı (Hdt. I. 152; Diod. IX. 36; ayrica bk. Balcer, 1984, 97 vd.; Briant, 2002, 36; Scott, 2005, 44-48).

Kyros Küçük Asya kentlerinin rahatlıkla boyun eğdirileceğini öngördüğünden, Sardeis’te bir garnizon kurup, küçük bir orduyu Pers Tabalos'un yetkisine bıraktı. İ.Ö. 546 y1lının ilkbaharında Kroisos'un da refakatiyle Babil, Baktria, Sakai ve Mısır'a düzenleyeceği askeri harekat için Ekbatana'ya doğru yola çıktı (Hdt. I. 153; Ksen. Kyr. VII. 4. 12; Polyain. strat. VII. 6. 4 'Kyros'; Iust. I. 7. 11-14). Hazineleri ve tutsakları getirmekle Lydia'lı Paktyes'i görevlendirdi. Kralın yokluğunu firsat bilen Paktyes ise, Lydia'lıları ayaklandırarak diğer isyancılarla temasa geçti ve Lydia hazineleriyle sahile inerek paralı askerler topladı. Kıyıdaki kentleri kendisiyle birlikte savaşa sürükledi. Ücretli askerlerle Sardeis'e ilerledi ve Tabalos'u ablukaya aldı. Dönüş yolundayken bunu haber alan Kyros ayaklanmayı bastırmakla Med Mazares'i görevlendirdi (Hdt. I. 156-157; Polyain. strat. VII. 6. 4 'Kyros'; Iust. I. 7. 11-13). Pers ordusunun geldiği haberi alınınca isyancılar dağıldılar. Khios'lular, Paktyes'i Mysia'daki Atarneos (Dikili) kentinin karşıllı̆ında Mazares'e teslim ettiler (Hdt. I. 160; FGrHist III A 262 F 9 'Kharon'=Plut. mor. XI. $859 a-b$; De Herod. 20). Mazares, Priene ve Magnesia dahil Menderes Ovası'n1 zapt edip yağmaladı, halkını köleleştirdi. Ancak kısa süre sonra hastalanıp öldü (Hdt. I. 161). Kyros yerine komutan olarak Harpagos (Hdt. I. 162: Diodoros (IX. 35)'de Kyros'un Harpagos'u kıy1 
kentlere komutanı olarak gönderdiğini aktarır), Hystaspas ve Adusios'u atadı (Ksen. Kyr. VII. 4. 1-7; VIII. 6. 7).

Harpagos saldırılarına Ionia'yla başladı. İlk önce dört yanı surlarla çevrili Phokaia'yı (Foça) (Hdt. I. 163; FGrHist III B 555 F $8<$ Antiokhos $>=$ Strab. VI. 1. 1 c. 252; Gell. X. 16. 4; Paus. X. 8. 6) kuşattı. Phokaia'lılar kentlerini terk edip Kyrnos'a geldiler. Bir kısmı burada kurdukları Alaia'ya yerleşirken, bir kısmı da Rhegium'a gitti (Hdt. I. 164-167; Paus. X. 8. 6; ayrıca bk. Asher, Lloyd, \& Corcella, 2007, 183 vd.). Phokaia'dan sonra Teos'a (Sığacık) saldırdı. Teos'lular da Phokaia'lılar gibi kentlerini boşaltılar. Trakya'ya gelip Klazomenai'lı (Urla) Timesios'un önceden kurduğu Abdera'ya yerleştiler (Hdt. 168). Geriye kalan Ionia kentleri -Klazomenai, Lebedos, Kolophon, Ephesos, Myous, Erythrai, Smyrna- ise, Harpagos'a direndiler; ancak yenilip Pers egemenliğine girdiler (Hdt. I. 168; ayrıca bk. Aiskhyl. Pers. str. 770; Thuk. I. 16). Herodotos (I. 169) kıyı kentlerin Perslere birer birer boyun eğdiğini görünce adalıların da kendiliğinden Pers egemenliğini tanıdıklarını aktarır. Ancak Herodotos (I. 143)'deki pasajında da belirtiği üzere, Kyros'un donanması ve bu sırada deniz üstünlüğünü elinde tutan herhangi bir müttefiki yoktu. Donanma gücünün yetersizliğinden dolayı adalara sefere çıkmayı ve deniz savaşı yapmayı göze almamış olsa gerektir. Bunu yanı sıra, dostluk ilişkileri ve siyasi stratejileriyle adalıların bir kısmına egemenliğini kabul ettirmiş olabilir (ayrıca bk. Hdt. I. 160 'Khios ve Paktyes anlatısı'). Ancak muhtemelen adalıların tümü Pers boyunduruğuna Fenike bağdaş1klığıyla deniz hakimiyetini sağlamasının ardından -Fenike ittifak ilişkisi II. Kambyses tarafından gerçekleştirilmiştir (Hdt. III. 19)-, Dareios zamanında girmiş olmalıdır (Thuk. I. 16; ayrıca bk. Hornblower, 2003², 49 vd.; Scott, 2005, 46 dn. 162).

Büyük olasılıkla Ionia seferinin ardından Harpagos ve Adusios Karia'ya ilerlediler. Harpagos büyük direniş göstereceği beklenilen kentlere yönelirken, muhtemelen Adusios da daha az sorunsuz bölgeler üzerine gitti. Karia'lllardan Pedasa'lllar haricinde -Lide Dağ dırılan mevkide Persleri sıkıştırıp, Harpagos'a uzun süre güçlük çıkarırlar- anılmaya değecek bir mücadele ve yiğitlik sergilemediler (Hdt. I. 171-176). Ksenophon (Kyr. VII. 4), Karia'llların mukavemet göstermeden Perslere kapılarını açmalarının nedenini o sırada partiler arasında yaşanan muhalefet kavgalarına bağlar. Bu iç karışıklık İ.Ö. ca. 547/546 yılındaki Sardeis ablukası esnasında patlak verir. Bir türlü uzlaşmaya varamayan Karia'lılar Kyros'tan yardım isterler. Adusios önderliğinde büyük bir ordu Karia'ya gönderilir. Kilikia ve Kyprios (Kıbrıs) da bu sefere gönüllü olarak Adusios'a iştirak ederler. Bu nedenle Kyros bu iki bölgeye satrap atamayıp, yerel dynastes'ler tarafından yönetilmesine müsaade eder. Adusios akılcı ve uzlaşmacı yaklaşımıyla Karia'lılar arasındaki sorunu kısa süre zarfında çözer. İki parti liderleri arasında bir barış antlaşması yapar. Buna göre, iki parti birbirleriyle kız alış verişinde bulunacak; tarlalarını rahatlıkla işleyebilecekler ve aralarında bir ittifak kuracaklardı. Antlaşmayı bozan taraf Kyros ile Persleri karşısına alacaktı (Ksen. Kyr. VII. 4. 3-7). Ardından Adusios bölgede garnizonlar kurup, kalelerde muhafizlar birakarak arta kalan orduyla Kyros'un yanına döner. Karia'l1lar sergilediği basiretli ve iyi niyetli tutumundan ötürü daha sonra Pers kralından Karia Bölgesi'ne satrap olarak Adusios'u atamasını talep ederler (Ksen. Kyr. VII. 4. 7).

Karia'nın ardından Harpagos Lykia seferine çıkarken (Hdt. I. 176), muhtemelen Hystaspas ile Adusios da karışıklık çıkaran Büyük Phrygia ve Hellespontos Phrygia'sına doğru ilerler. Aiskhylos (Pers. str. 770) da Kyros'un Lydia ve Ioina'dan sonra Phrygia'ya boyun eğdirdiğini belirtir. Ksenophon (Kyr. VII. 4) ve Zonaras'a (epit. hist. 1. 252-253) göre Hellespontos Phrygia'sındaki kıyı kentler, fazla direnmeden Pers ordularına çeşitli hediyeler sunup Kyros'a haraç vermeyi; onunla birlikte sefer katılmayı ve asker göndermeyi kabul ederler. Phrygia kralı ise, Perslerle sonuna kadar savaşmayı kararlaştırır. Lakin adamlarının ilk çarpışmada kendisini yalnız bırakmaları nedeniyle Hystaspas'e teslim olmak zorunda kalır. Pers komutanı bölgede muhafızlar bırakıp, kralın emri uyarınca Phrygia'dan topladığı süvari birliğiyle geri döner. Zira 
Kyros, Adusios ve Hystaspas'a Phrygia'lllardan kendilerine katılmak isteyenleri; aynı zamanda direnenleri silahları ve atlarıyla alıp getirmelerini buyurdu (Ksen. Kyr. VII. 4. 10-11). Babilli Agathokles'in (FGrHist III B 472 F 6=Ath. Deip. I. 54; Eust. Comm. ad Hom. Il. III. 183) anlatısına istinaden Kyros, Hellespontos ve Phrygia civarlarından yedi kentin; Pedasos, Olympion, Akamantion, Tion, Skeptra, Artypsos ve Tortyra'nın yönetimini dostu Kyzikos'lu Pytharkhos'a devretti. Ancak Pytharkhos bu kentleri uzun süre elinde tutamadı. Kibrin ve küstahlığın pençesine düşüp, Kyzikos tiranı olma sevdasına kapılınca halk büyük bir direniş sergileyip, onu ağır bir hezimete uğrattı.

Harpagos ise, zapt ettiği yerlerden de beslendiği büyük bir orduyla Ksanthos Ovası'na geldi. Düşman sayısına aldırış etmeyen Ksanthos'lular savaş meydanında yerlerini aldılar. Bağımsızlıkları uğruna büyük bir mücadele sergilediler. Ne var ki, yenilip kentlerine çekilmek zorunda kaldılar. Esaretin pençesine düşen eşleri, çocukları, hazineleri, köleleri kaleye doldurup ateşe tutuşturdular. Ksanthos'ta eli kılıç tutanlar, sonuna kadar çarpışarak savaş meydanında can verdiler (Hdt. I. 176; ayrica bk. Appian. civ. IV. 76-80; Plut. Brut. XXXI. 4-8; XXXI. 1-7; Cass. Dio XLVII. 34). Kaunos'lular da Ksanthos örneğini izleyip özgürlükleri adına giriştikleri mücadelede sonuna kadar direnseler de Pers boyunduruğu altına girmekten kurtulamadılar (Hdt. I. 176).

Kyros, Sardeis'in düşüşünden yaklaşık yedi yıl sonra İÖ. ca. 539 y1lında Babil'i de egemenliğine kattı. Kyros Silindiri'ne (str. 15-16: Spek, 1982, 278-283; Kuhrt, 1983, 83-97; Hallo, \& Younger, 2003, 314-317) istinaden Pers kralı tanrı Marduk'un inayeti ve teşvikiyle Babil üzerine sefere çıktı. Antik kaynaklarında mutabık olduğu üzere kenti savaşmadan ve kan dökmeden ele geçirdi. Babil kralı Nabonidos'un yurtlanından ettiği Yahudileri ülkelerine geri getirdi ve Kudüs'te yeni bir tapınak inşa ettirdi (Kyros Silindiri str. 1-45; Hdt. I. 188-191; Ksen. Kyr. V. 2. 1-22; VII. 5. 1-30; FGrHist III C 1680 F 9a; $9 b$ (146-153) 'Berossos'=Ioseph. Cont. Ap. I. 133145; Polyain. strat. VII. 6. 3 'Kyros'; Iust. I. 7. 3-10; Zonar. epit. hist. 1. 254-255; ayrica bk. Olmstead, 1959, 45; Burn, 1962, 48-61; Mallowan, 1972, 9-11; Dandamaev, 1989, 38-65; Balcer, 1995, 69-73; Briant, 2002, 44-48; Kuhrt, 2007b, 70-87; 2007d II, 289-296; 370 vd.).

Kyros zaferlerinin ardından hakimiyeti altına aldığı topraklarda istikrar ve güvenliği sağlamak amacıyla garnizonlar kurdu. Babil'in fethiyle, İÖ. ca. 539 yılında, kral unvanını aldıktan sonra buralarda idari yapılanmalar içine girdi. Eski Persçe'de xšaçapāvan "krallığın koruyucusu"

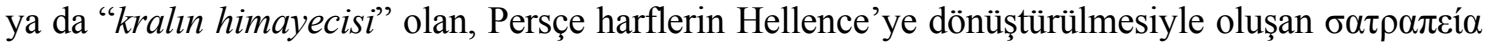

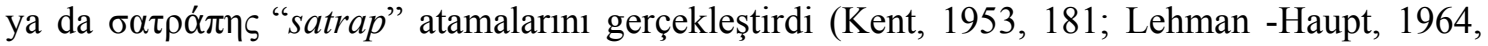
col. 82; Petit, 1999, 15 vd.; Klinkott, 2005, 28-29). Gerçi xšaçapāvan ilk olarak İ.Ö. 522 yılında, I. Dareios'un res gestae niteliğindeki Behistan-Bisutun yazıtında belgelense de, antik kaynaklar ve Ezra'nın aktarımlarından bu düzenlemeyi ilk olarak Kyros'un yaptığı bilinmekte ve genel kabul görmektedir. İ.Ö. 535 y1lında Gubaru'yu (Gobryas) "Babil ve Euphrates'in ötesinin" valisi (pihatu) olarak tayin etti (Ezra 6: 2). Knidos'lu Ktesias'a (FGrHist III C 1 F 9 $(8)=$ Phot. Bib. 72. 37a) göre, ölümünden kısa bir süre önce, İÖ. ca. 530/529 y1lında, oğlu Bardiya'ya (= Smerdis/Tanyoksarkes) Baktria, Khoramnia, Parthia ve Karmania'nın yönetimini devretti. Üvey oğulları Spitakes'i Derbikes; Megabernes ise, Barkania'lıların satraplığına getirdi. Küçük Asya'da ise, sınırları Lydia ve Ionia'yı kapsayan Sardeis (Sart) satraplık merkezine Pers

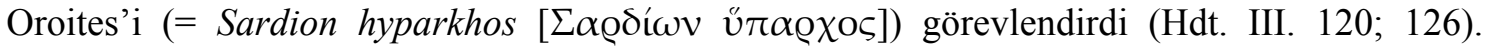
Oroites'in Sardeis'in yanı sıra Magnesia ad Maendrum'da (Manisa) da ikamet etmesi (Hdt. III. 122; 125); ayrica Ksenophon (VIII. 6. 7-8) ve Zonaras'ın (epit. hist. I. 260) Kyros'un atamalarında, Lydia ile Ionia'yı aynı satraplıkta vermeleri bunu doğrular niteliktedir (Briant, 2002, 64; ayrıca bk. Balcer, 1993, 81-90; Dusinberre, 2003, 35 vd.). Küçük Asya'da Sardeis'in yanı sıra bir diğer önemli satraplık merkezi Daskyleion (= Tyaiy drayahyā/Hisar Tepe)'dir. Herodotos (III. 120)'de Lydia valisi Oroites'i Kyros'un atadığını belirtirken; Daskyleion valisi Mitrobates'in kimin tayin ettiğine değinmez. Bunun yanı sıra, Kyros ya da Kambyses tarafindan görev- 
lendirildiğine şüphe yoktur. Herodotos (III. 120-127)'deki pasajlarında uzun uzadıya yer verdiği Oroites ile Mitrobates arasındaki rekabet anlatısına istinaden, iki satrap arasında köklü düşmanlık göz önünde bulundurulduğunda Oroites'le eş zamanda görevlendirilmesi daha olasıdır. Ksenophon'a (Kyr. VIII. 6. 7-8) göre ise, Pers kralı yakın çevresindeki güvenilir ve deneyimli komutanlarından Arabia'ya Megabyzos'u; Kappadokia'ya Artabatas'1; Büyük Phrygia'ya Artakamas'1; Lydia ve Ionia'ya Khrysantas'1; Karia'ya Adusios'u; Hellespontos üzerindeki Phrygia ve Aiolia'ya Pharnukhos'u satrap atadı. Zonaras (epit. hist. I. 260)'de satrapların adların belirtmez sadece bu bölgelerin Arabia; Kappadokia; Büyük Phrygia; Lydia ve Ionia; Karia; Hellespontos Phrygia'sı ve Aiolis olduğunu kaleme alır. Her iki historiograf da Kyros'un Karia ve Babil seferlerine gönüllü olarak katıldıklarından Kilikia, Kıbrıs ve Paphlagonia'ya satrap atamayıp, yerel dynastes'lerin idaresinde yönetilmesine müsaade ettiği hususunda hem fikirdirler. Bu bölgeleri vergi ödemekle ve savaş esnasında asker göndermekle mükellef tutar. Bunun yanı sıra, aynı şekilde Lykia da yerel dynastes'lerin egemenliği altında yönetilmeye devam etmiş görünmektedir (Briant, 2002, 63 vd.; Wiesehöfer, 2003, 101).

Büyük II. Kyros İ.Ö. ca. 559 yılında devraldığı küçük Anša hanedanlığını 200 y1l boyunca Küçük Asya ve Merkez Asya'nın büyük bir kısmına hüküm eden bir imparatorluk haline getirdi. Vasal krallığın başına geçtiğinde askeri, siyasi ve savunma sistemine öncelik verip, zamanın en güçlü krallarını birbiri ardına boyun eğdirdi. Saltanatının yaklaşık ilk dokuz yılında (İ.Ö. ca. 559-ï.Ö. ca. 550/549) hanedanlığını Med hakimiyetinden kurtarmakla kalmayıp aynı zamanda Med krallığını tarih sahnesinden silerek kendi hakimiyeti altına aldı. Med krallığının bir ardılı olarak Halys Irmağı bundan böyle Pers ve Lydia krallıkları arasında bir huduttu. İ.Ö. ca. 547/546 yılında, emperyalist politikalarının kaçınılmaz bir sonucu olarak, Kappadokia üzerindeki emelleri iki krallığı karşı karşıya getirdi. Lykia ve Kilikia hariç Batı Anadolu'yu ve ticaret ağını egemenliği altında tutan Lydia kralı Kroisos'u beklenilenin aksine daha Pteria'daki ilk savaşta ağır bir yenilgiye uğrattı. Basireti ve askeri öngörüsüyle kış olmasına rağmen, tanımadığı düşman territorium'un içlerine kadar sokulup Kroisos'un topraklarında çarpışmayı göze aldı. Büyük bir direnişin ardından Sardeis akropolis'ini zapt edip Lydia krallığını egemeliği altına ald1. Sardeis'in düşüşüne müteakiben, İ.Ö. ca. 546, Harpagos önderliğinde Miletos ile Kyklades adalarının büyük bir kısmı haricinde Ionia, Karia, olasılıkla Hellespontos ve Büyük Phrygia, Lykia'yı da Pers yönetiminin bir parçası haline getirdi. İ.Ö. 539 yılında Babil'i de krallığına dahil ederek karşı konulamaz bir güce ulaştı. Askeri başarılılarını, siyasi-idari yapıda gerçekleştirdiği düzenlemelerle pekiştirdi. Böylelikle hem krallık merkezinde hem de boyunduruk altındaki bölgelerde politik istikrarı, toplumsal düzeni ve iktisadi kalkınmayı sağladı. Krallığının başkentini Pasargadai'ya taşıdı. Med ve Lydia hazinelerini Pasargadai'ya nakledip krallık merkezinde ekonomik bir refah sağladı. Fethedilen yerlere garnizonlar kurup bu yerlerin güven ve istikrarını temin etti. İlk olarak Assurların organize edip, yürürlüğe koyduğu ve Assur çivi tabletlerinde lípīhātu/bēl pīhăti şeklinde ifade edilen satraplık idari sistemini Pers imparatorluğuna uyarladı. İ.Ö. ca. 553 yılından itibaren fethedilen yerlerin bazılarına satraplar tayin ederken; büyük olasılıkla Kilikia, Paphlagonia ve Lykia gibi kentlerin bir kısmına özerklik tanıdı ve yönetimi yerel hanedanlıklara bıraktı. Bu bölgeleri vergiden ziyade haraç ya da hediye vermek ve istenildiğinde asker göndermekle mükellef tuttu.

Babil çivi yazılı tabletleri, Eski Ahit metinleri ve antik kaynakların bütününde Kyros'un olumlu bir portresi çizilmektedir. Sippar Silindiri'nde: Tanrı Marduk'un ağzından Med krall1ğını devirecek ve birçok beylikleri dize getirecek güçlü bir kral olarak betimlenir. Nabonidos Kroniği'nde: Astyages'i yenip Med krallığının başkenti Ekbatana'yı yağmalatan ve ganimeti kendi ülkesi $A n s ̌ a '$ ya taşıtan bir fatih olarak zikredilir. Pers kralının başarı anlatımı ve hükümdarlığının meşrulaştırma çabası olarak değerlendirilen Kyros Silindiri'nde: Dindarlığı, adilliği, dürüstlüğü nedeniyle Marduk'un Kyros'u Babil kralı seçtiği; tanrının inayeti ve teşvikiyle Babil 
üzerine sefere çıkan; savaşmadan ve kan dökmeden kenti ele geçiren; yaptığı tadilat ve düzenlemeyle kentin refahını sağlayan barışçıl bir hükümdar şeklinde tasvir edilir. Eski Ahit metinlerinde Ezra ve Nehemya kitaplarında Kudüs Tapınağı'nın restore edip, Yahudi sürgünleri geri getiren, ümitle gelmesi beklenilen bir kurtarıcı olarak tanıtılır. Bir tek, Opis'te Babil ordusunu mağlup ettikten sonra kenti yağma edip esir alınanları katlettiği kaydedilen bir çivi tabletinde Kyros'un olumsuz bir özelliği vurgulanmaktadır. Antik yazarlar ise, Pers kralları arasından yalnızca Kyros'u alçak gönüllüğü, basireti ve kahramanlıklarıyla uyrukları tarafından " $b a b a$ " diye adlandırılan (Hdt. III. 89; Ksen. Kyr. VIII. 8. 1-2; Diod. IX. 24), askeri, siyasi-idari stratejisi, becerisi ve yüce gönüllülüğüyle, Astyages ve Kroisos gibi düşmanlarına dostluk, cömertlik, insaf ve şefkat gösteren biri olarak tasvir ederler. Bu yönüyle Kyros zamanla tarihsel gerçeklere hizmet etmek yerine, ideal bir devlet adamında olması gereken özellikleri kendi vasfinda toplayan örnek bir kral ya da imparatorun timsali haline getirilir.

\section{KAYNAKÇA}

AMI Archäologische Mitteilungen aus Iran.

AAraş. Anadolu Araştırmaları.

App. Appianus, Rhomaika: Appian's Roman History. Trans. H. White I-IV (1912-1913). Cambridge, Mass.-London: Loeb.

Aristot. Rhet. Aristoteles, On Rhetoric: a theory of civic discourse. Trans. with introduction, notes and appendices by G. A. Kennedy $\left(2007^{2}\right)$. New York: Oxford University Press.

Ath. Deip. Athenaios, The Deipnosophistis. Trans. C. B. Gulickvol. I-VII (1927-19996). Cambridge, Mass.-London: Loeb.

AS Anatolian Studies.

Asher, A., Lloyd, A., \& Corcella, A. (2007). A Commentary on Herodotus Books I-IV. New York: Oxford University Press.

Bacchyl. Bacchylide. Dithyrambes, epinicies, fragments. Ed. J. Irigoin (1993). Paris: Les Belles Lettres.

Balcer, J. M. (1984). Sparda by the Bitter Sea: Imperial interaction in Western Anatolia. Chico, California: Brown University.

Balcer, J. M. (1993). The Ancient Persian satrapies and satraps in Western Anatolia. AMI, 26, 81-90. Berlin.

Balcer, J. M. (1995). The Persian Conquest of the Greeks 545-450 B.C. Konstanz: Universitätsverlag Konstanz.

Briant, P. (2002). Histore de I'Empire perse. Paris 1996: Çeviri: From Cyrus to Alexander: A History of the Persian Empire. Trans. P. T. Daniels. Winona Lake, Indiana: Eisenbrauns.

Brosius, M. (2006). The Persians. London, New York: Routledge.

Burn, A. R. (1962). Persia and the Greeks the Defence of the West, c. 546-478 B.C. London: Edward Arnold Publisher.

Cahill, N. (2010). Sardeis'te Pers Tahribi: The Persian Sack of Sardeis. Ed. N. D. Cahill. Lydalılar ve Dünyalarl; The Lydians and their World, 339-362. İstanbul: T. C. Kültür ve Turizm Bakanlığı \& Yap1 Kredi Kültür Sanat Yayınc1lı.

CAH The Cambridge Ancient History.

Cass. Dio Cassius Dio, Rhomaika: Roman History. Trans. E. Carry I-IX. (1914-1927). London: Loeb.

CHI The Cambridge History of Iran.

Chalc. Chalcidius, Ex Graecis Conversiones (Fragmenta Poetarum Latinorum Epicorum et Lyricorum praeter Ennium et Lucilium). Ed. W. Morel (1927). Teubneri.

Cic. Sen., div. Cicero, On Old Age; Divination. Trans. W. A. Falconer $\left(2001^{13}\right)$. Cambridge, Mass.-London: Loeb.

Cic. de nat. deor. Cicero, De Natura Deorum. vol. XIX. Trans. H. Rackham $\left(1967^{4}\right)$. Cambridge, Mass.London: Loeb. 
ClassAnt Classical Antiquity.

CQ The Classical Quarterly.

Cook, J. (1983). The Persian Empire. London, Melboune, Toronto: Schocken Books.

Cook, J. M. (1985). The Rise of the Achaemenids and Establishment of their Empire. CHI, II, 200-291. Cambridge.

Curtis, V. S., \& Stewart, S. (2005). Birth of the Persian Empire. London, New York: I. B. Tauris.

Dandamaev, M. A. (1989). A Political History of the Achaemenid Empire. Trans. W. J. Vogelsang. Leiden: Brill.

Dio Khrys. Orat. Dio Chrysostomus, Discourses, vol. III. Trans. J. W. Cohoon, \& H. L. Crosby $\left(2006^{6}\right)$. Cambridge, Mass.-London: Loeb.

Diod. Diodorus of Sicily. Trans. R. M. Geer (1947). London, New York: Loeb.

Diog. Laert. Diogenes Laertios, Lives of Eminent Philosophers. Trans. R. D. Hicks, vol. I-II (1935-2005 $\left.{ }^{11}\right)$. Cambridge, Mass.-London: Loeb.

Dönmez, Ş. (2004). Akalan Hakkında Yeni Gözlemler. AAraş, 17, 67-91. İstanbul Üniversitesi Edebiyat Fakültesi Yayınları.

Drews, R. (1969). The Fall of Astyages and Herodotus' Chronology of the Eastern Kingdoms. Historia, 18, 1-11. Stuttgart.

Dusinberre, E. R. M. (2003). Aspects of Empire in Achaemenid Sardis. Cambridge: Cambridge University Press.

Eust. Comm. ad Hom. Il. Eustathius, Eustathii archiepiscopi Thessalonicensis commentarii ad Homeri Iliadem pertinentes. Ed. M. van der Valk, vol. I-IV (1: 1971; 2: 1976; 3: 1979; 4: 1987). Leiden: Brill.

Favorin. fort. Favorinus Philosophus, Fragmenta: Favorino di Arelate. Ed. A. Barigazzi (1966). Florence: Monnier.

FGrHist Die Fragmente der griechischen Historiker. F. Jacoby. 1-XV. Berlin-Leiden.

Frontin. strat. Sextus Iulius Frontinus, The Strategems and the Aqueducts of Rome. Trans. C. E. Ennett (1925). London, New York: Loeb.

Frye, R. (1983). The History of Ancient Iran. München, Beck: Handbuch der Altertumswissenschaft Abt 3, Teil 7.

Gell. Aulus Gellius, Noctae Atticae: The Attic Nights of Aulus Gellius. Trans. J. C. Rolfe I-III. (1927-1928). London, New York: Loeb.

Glassner, J. J. (2004). Mesopotamian Chronicles: Writings from the Ancient World. Atlanta: Society of Biblical Literature.

Grayson, A. K. (1975). Assyrian and Babylonian Chronicles. Locust Valley, New York: J. J. Augistin Publisher.

GRBS Greek, Roman and Byzantine Studies.

Hallo, W. H., \& Younger, K. L. (2003). The Context of Scripture. Vol. II: Monumental Inscriptions from the Biblical World. Leiden and Boston: Brill.

Hansman, J. (1985). Anshan in the Median and Achaemenian Period. CHI, II, 25-35. Cambridge.

Harpok. lex. Harpokration, Lexicon in decem oratores Atticos. Ed. W. Dindorf (1853). Harpocrationis lexicon in decem oratores Atticos, vol. I., 1-310. Oxford: Oxford University Press, (repr. Groningen: Bouma, 1969).

Hdt. Herodotus. Trans. A. D. Godley I-IV (1975). London, New York: Loeb.

Hes. lex. Hesychius Alexandrinus, Hesychii Alexandrini lexicon. Vols. I-II [A-O]. Ed. K. Latte (I. 1953; II. 1966: 3-492; 1-806). Copenhagen: Munksgaard.

Historia Zeitschrift für alte Geschichte; Revue d' Histoire Ancienne; Journal of Ancient History; Rivista di Storia Antica. Stuttgart.

Hornblower, S. $\left(2003^{2}\right)$. A Commentary on Thucydides, vol. 1, books I-III. Oxford: Clarendon Press.

How,W. W., \& Wells, J. (1975²). A Commentary on Herodotus, I-II. Oxford: Clarendon Press.

Huxley, G. (1965). A War between Astyages and Alyattes. GRBS 6, 201-206. Durham. 
Ioseph. Cont. Ap. Iosephus, Against Apion. Trans. H. St. J. Thackeray (1976). Cambridge, Mass.-London: Loeb. Flavii Iosephi opera, vol. 5. Ed. B. Niese (1889). Berlin: Weidmann.

Iust. Marcus Iulianus Iustinus, Epitome of the Philippic History of Pompeius Trogus. Trans. J. C. Yardley (1994). With introduction and explanatory notes by R. Develin. Atlanta, GA.

Kent, R. G. (1953). Old Persian. New Haven: American Oriental Society.

Klinkott, H. (2005). Der Satrap ein Achaimenidischer Amtsträger und seine Handlungsspielräume. Frankfurt: Verlag Antike.

Kuhrt, A. (1983). The Cyrus Cylinder and Achaemenid Imperial Policy. JSOT 25, 83-97. London, Thousand Oaks, CA and New Delhi.

Kuhrt, A. (2007a). The Persian Empire. Ed. G. Leick. The Babylonian World. 562-276. New York and London.

Kuhrt, A. (2007b). The Persian Empire. A Corpus of Sources from the Achaemenid Period. Vol. II. London: Routledge: British Library Cataloguing.

Kuhrt, A. (2007c). Ancient Near Eastern History: The Case of Cyrus the Great of Persia. Proceedings of the British Academy 143, 107-127. Oxford: Oxford University Press fort he British Academy.

Kuhrt, A. (2007d). The Ancient Near East c. 3000-330 BC, vol. I-II. London 1995. Eski Çăg'da Yakındoğu MÖ. 3000-330. Çev. D. Şendil. İstanbul 2007: Türkiye İş Bankası Kültür Yayınları.

Ksen. Kyr. Xenophon, Cyropaedia. Ed. E. C. Marchant $\left(1970^{2}\right)$. Xenophontis opera omnia, vol. 4. Oxford: Clarendon Press.

JSOT Journal for the Study of the Old Testament.

Lagdon, S. (1912). Die neubabylonischen Konigsinschriften. Leipzig: Vorderasiatische bibliothek. [4. Stück].

Lapini, W. (1999). Talete e l'eclissi del 585 (11 A 5 DK). ZPE, 126, 115-116. Bonn.

Lehman,-,Haupt, F. (1964). Satrap. RE, II A/1, col. 82-188. Stuttgart.

Malal. chron. Malalas, Chronographia. Ed. L. Dindorf (1831). Corpus Scriptorum Byzantinae Historiae. Bonn.

Mallowan, M. (1972). Cyrus the Great (558-529 B.C.). British Institute of Persian Stuedies. Iran, 10, 117. Oxford.

Mela Pomponius Mela, Pomponius Mela's Description of the World. Trans. F. E. Romer (1998). Ann Arbor: The University of Michigan Press.

Müller, D. (1997). Topographischer Bildkommentar zu den Historien Herodots, I. Griechenland: Kleinasien und angrenzende Gebiete mit Südostthrakien und Zypern. II. Tübingen.

Nicol. Nicolaus Damascenus, FGrHist Die Fragmente der griechischen Historiker (Fragments of the Greek Historians), F. Jacoby. (Ed. E. J. Brill) Leiden 1958. Fragmenta. Ed. K. Müller (1841-1870: 348-464. Frr. 1-147). FHG III. Paris: Didot.

Oates, J. (2006 ${ }^{6}$ ). The fall of Assyria (635-609 B.C). CAH III/2, 162-189. Cambridge, London.

Olmstead, A. T. (1959). History of the Persian Empire. Chicago: The University of Chicago.

Oxyrh. Pap. Oxyrhynchus Papyri XIII. Editit with Trans. and Notes by B. P. Grenfell, \& A. S. Hunt (1919). London.

Parthen. amat. Parthenius, Narrationes Amatoriae. Ed. E. Martini (1902). Parthenii Nicaeni quae supersunt [Mythographi Graeci. I, suppl. Leipzig: Teubner]: 41-92.

Paus. Pausanias, Pausanian Description of Greece. Trans. W. H. Jones I-V. (1918-1935). London, New York: Loeb.

Pedley, J. G. (1972). Ancient Literary sources on Sardis. Cambridge, Massachusetts: Harvard University Press.

Pelling, C. (2006). Educating Croesus: Talking and Learning in Herodotus' Lydian Logos. ClassAnt, 25, 141-177. University of California Press.

Petit, T. (1990). Satrapes et satrapies dans l'empire achéménide de Cyrus le Grand á Xerxès $I^{e r}$. Paris: Les Belles Lettres.

Philostr. de Imag. Flavius Philostratus "Yaşlı", Imagines. Trans. A. Fairbanks. Ed. J. Henderson $\left(2000^{6}\right)$. 
Cambridge, Mass.-London: Loeb.

Phot. Bib. Photios, Bibliotheka. Ed. R. Henry (1971). Paris.

Plut. Alex. (Alexandrus), Artaks. (= Artakserkses), Sol. (= Solon) Plutarkhos, Plutarch's Lives. Trans. B. Perrin I-XI (1959). London, New York: Loeb.

Plut. mor. Plutarkhos, Plutarch's Moralia. Trans. F. C. Babbitt, \& W. C. Helmbold I-XIV (1928-1967). London, New York: Loeb.

Polyain. strat. Polyainos, Strategemata. Ed. E. Woelfflin, \& J. Melber (1887 (repr. Stuttgart: 1970): 2-301, 305-425). Leipzig: Teubner.

Polyb. Polybios, The Histories. Trans. W. R. Paton I-VI (1922). Cambridge, Mass.-London: Loeb.

Pomp. Trog. prolog. Pompeius Trogus, Prologues to the Philippic History of Trogus. Trans. J. C. Yardley (1994). With introduction and explanatory notes by R. Develin. Atlanta, GA.

Potts, D. T. (2004). The Archaeology of Elam: Formation and Transformation of an Ancient Iranian state. New York: Cambridge University Press.

Pritchard, J. B. $\left(1969^{2}\right)$. Ancient Near Eastern Texts Relating to the Old Testament. New Jersey: Princeton University Press.

RE Paulys Real-Encyclopädie der classichen Altertums-wissenschaft.

Schol. Lucan. Lucianus Scholia in Lucianum (scholia vetera et recentiora Arethae). Ed. H. Rabe (1906 (repr. Stuttgart: 1971): 1-285). Leipzig: Teubner.

Schol. Plat. Rep Scholia in Platonem, Respublica (scholia vetera). Ed. W. C. Greene (1938: 1 1-405, 407-413). Scholia Platonica. Haverford, Pennsylvania: American Philological Association.

Schott, L (2005). Historical Commentary on Herodotus Book 6. Leiden, Boston: Mnemosyne.

SEG Supplementum Epigraphicum Graecum.

Sherk, R. K. (1969). Roman Documents from the East. Baltimore: University of California.

Smith, S. (1924). Babylonian Historical Texts. London: Methuen \& Co. Ltd.

Spek, R. J. (1982). Did Cyrus the Great introduce a new policy towards subdued nations? Persica, 10, 278-283. Leiden: Nederlands Instituut voor het Nubije Osten.

Strab. Strabon, The Geography of Strabo. Trans. H. L. Jones I-VIII (1917-1932). London, New York: Loeb. Steph. Byz. Ethnika Stephanos Byzantios, Stephani Byzantii, Ethnikon. Ed. A. Westermann (1839). Libsae.

Stronach, D. (1997). Anshan and Parsa: early Achaemenid history, art and architecture on the Iranian Plateau. Ed. J. Curtis. Mesopotamia and Iran in the Persian Period: Conquest and Imperialism, 539331 BC., 35-53. London: British Museum.

Suda Suda-Suidas, Suidae Lexicon. Ed. A. Adler I-IV (1928-1971). Leipzig: Teubner.

Summers, G. D., Summers, M. E. F., Baturayoğlu, N., Harmansah, O., \& McIntosh, E. R. (1996). The Kerkenes Dag Survey: An Interim Report. $A S$, 46, 201-234. London.

Syll $^{2}$ Sylloge Inscriptionum Graecarum. Ed. W. Dittenberger. Leipzig.

Tadmor, H (1965). The Inscriptions of Nabunaid: Historical Arangement. Studies in Honor of Benno Landsberger on his Seventy-Fifth Birthday. Assyriological Studies, 16, 351-363. Chicago.

Theon, Theonis Smyrnaei philosophi Platonici expositio rerum mathematicarum ad legendum Platonem utilium. Ed. E. Hiller (1878). Leipzig: Teubner.

Theophr. fr. Theophrastus Philosophus, Theophrasti Eresii opera, quae supersunt, omnia. Ed. F. Wimmer 1866 (repr. Frankfurt am Main: Minerva, 1964): 364-410, 417-462. Paris: Didot.

Thuk. Thukydides, Peloponnes Savaşı. Çev. T. Gökçöl (1976). İstanbul: Hürriyet Yayınları.

Tzet. Chil. Tzetzes, Historiarum Variarum, Chiliades. Ed. T. Kiessling (1826) Leipzig: Lipsiae.

Val. Max. Valerius Maximus, Factorum et dictorum memorobilium libri novem. Iulii paridis et Ianuari nepotiani epit. adiectatis. Rec.: C. Halm (1865): Teubner.

Waters, M. (2004). Cyrus and the Achaemenids. Iran 42, 91-102. London.

West, S. (2003). Croesus' Second Reprieve and Other Tales of the Persian Court. CQ 53, 416-437. Oxford.

Weippert, M. (2010). Historischen Textbuch zum Alten Testament: Grundrisse zum Alten Testament. Germany: Vandenhoeck, \& Ruprecht. 
Wiesehöfer, J. (2003). Antik Pers Tarihi. Çev. M. A. İnci. İstanbul: Telos Yayıncılık.

Young, T. C. $\left(2006^{6}\right)$. The early history of the Medes and the Persians and the Achaemenid empire to the death of Cambyses. $C A H, I V^{2}, 1-47$. The consolidation of the empire and its limits of growth under Darius and Xerxes. CAH IV $V^{2}$, 47-79. Cambridge, London: Cambridge University Press.

ZPE. Zeitschrift für Papyrologie und Epigraphik.

Zonar. Zonaras, Ioannis Zonarae epitome historiarum, vol 3. Ed. L. Dindorf (1868). Leipzig: Teubner. 